\title{
Chinese Feminism in Transformation Looking Eastward and Embracing Eastern European Feminisms?
}

\author{
Qi Wang \\ Department of Design and Communication \\ University of Southern Denmark
}

\begin{abstract}
Feminism in post-socialist China sprouts and develops in the context of globalization and transnational feminism. In tandem with the country's 'opening up', Chinese feminism has sought to be 'connected' (jiegui) with international feminism in order to break away from the Maoist confine and the state-dictated gender ideology and political praxis. The 'international' feminism that has 'travelled to' China, however, turns out to be overwhelmingly US feminist -theories, and, over the latest years, a self-reflection over this leaning-to-one-side (the west) and the tilted power relations between Chinese and US feminism has come to a clear articulation in the Chinese feminist community. This paper joins the debate. It brings in Eastern European feminisms (EEF) and discusses the potential of EEF in becoming a new source of inspiration for feminist theorizing and organizing in China. Starting with a brief account of the Eastern Europe's post-socialist transition and encounter with Western feminism, the paper outlines four central tenets of Eastern European feminisms and dwells upon how these constitute a formidable challenge to the hegemony of Western feminism. In the end, the paper discusses the prospect of looking eastward and embracing Eastern European feminisms and points out the relevance of Eastern European feminisms for the transformation of Chinese feminism.
\end{abstract}

Keywords: China, feminism, post-socialist feminism, Eastern European feminism, gende

\section{Introduction}

This article introduces Eastern European feminisms and discusses the potential of Eastern European feminisms in becoming a new source of inspiration for feminist theorizing and organizing in China. The reason for why we should now turn our eyes to Eastern Europe is manifold. First and foremost, it is because Eastern European feminisms, after 'a period of 
defeatism and self-doubt', have emerged 'as diverse and multidimensional sites of political dialogue locally and globally' (Grabowska, 2012:385) and have hence constituted a formidable challenge to the hegemony of Western feminism. In other words, a new rival has announced her arrival in the global horizon of feminist power constellation after Black feminism and postcolonial Third World feminism, and this will significantly alter the pattern of power balance in the international politics of feminism. For a long time, 'feminism' has remained a politically controversial label which connotations, standpoints, and sociopolitical relevance have been constantly questioned, contested, tailored and remolded. Although it has been accepted as a common knowledge nowadays that there is no one singular 'feminism' but many different 'feminisms', the emergence of Eastern European feminisms has not only boosted the confidence of a geopolitical region other than the West in claiming feminist gender knowledge but also added a good volume to the multiplicity of global feminism.

Secondly, Eastern European feminisms are interesting because they brought in a third category to the 'transnational feminism which is primarily framed as 'a dialogue between women from the global North and the global South', or between the West and non-West. Eastern European feminisms open a third path and urge for recognition of 'the second world as a site of global struggles' as well (Grabowska, 2012: 387). And, as the second world Eastern Europe-situates in various post-socialist political contexts, the arrival of Eastern European feminisms will also draw our attention to the relevance of other social categories, such as 'historical era' (Cerwonka, 2008:815), than the extant geography-wise, geopoliticswise and race-wise taxonomy of feminism (in this case, the white and black) in global feminist thinking and analysis. In this sense, "historical era' as a category would better allow us to reflect on the various deep-rooted historical conditions/circumstances that led up to the post-socialist transition of the Eastern Europe and on how these conditions/circumstances have shaped the trajectory of feminism in the Eastern Europe an countries (Ghodsee, 2004: 729).

Thirdly, the interest in Eastern European feminisms grows out of the fact that women in China are facing some strikingly similar challenges as women do in the Eastern Europe. Despite the distance in geographic sense, China and Eastern Europe share a quite similar historical path of development characterized by a communist regime plus a socialist economy in the socialist era and then the transition to a market economy in the post-socialist epoch. In both post-socialist China and Eastern Europe, volte-face changes in gender relations have manifested and been felt in society along with the reworking of normative gender notions and the redefinition of women's role in transitional economy. More similarly is the opening of China and Eastern Europe to the West and the subsequently 'import' of Western feminism, for instance in terms of the 'gender' concept, NGO organizing, Women's Studies and various feminist diagrams of research. And, perhaps, the growing frustration over the applicability of Western feminism that has been voiced loudly by the Eastern European feminisms echoes a likely concern of Chinese feminism in the current feminist debates in China. For all the 
reasons, it may prove to be a good idea to dig into the tenet of Eastern European feminisms and see what invaluable source of reference and inspiration can be drawn from there.

To begin with, let me clarify the usage of terms. In general sense, the term 'Eastern Europe' refers to a sub-region of Europe, including the countries of Russia, the Czech Republic, Poland, Hungary, Romania, Moldova, Croatia, Lithuania, Latvia, Estonia, Slovenia, Slovakia, Bulgaria, Ukraine, Belarus, Serbia, Montenegro, Bosnia and Herzegovina, Albania, Kosovo and Macedonia. ${ }^{1}$ Sometimes, the term CEE is used to refer to a further sub-region The Central and East Europe consisting of the Czech Republic, Hungary, Poland, Croatia, Slovenia, Slovakia and Moldova. ${ }^{2}$ Eastern European feminisms, as a rubric, refer to the various feminism streams emerged from this vast region, more in some countries and less in some others. Apart from the term 'Eastern European feminisms' itself, two other different terms are often used interchangeably to depict the same, and they are 'second world' and 'post-statesocialist' (Grabowska, 2012). In other words, Eastern European feminisms can also be called (understood as) 'second world feminisms' and/or 'post-state-socialist feminisms. The only difference is that last term carries an emphasis on the historical condition of feminism in this region, whereas the first and the second one convey a more salient regional and geopolitical aspect in the connotation.

While no exact date can be attributed to the birth of Eastern European feminisms, it is generally held that the socioeconomic, political and cultural changes throughout the 1990s and onwards prepared the soil for Eastern European feminisms to sprout. To describe what Eastern European feminisms stand for is, however, a daunting task with serious challenge in source selection/collection and a high risk of possible misrepresentation. This article will thus stay humble in both its' approach and goal: it will draw a modest sketch of Eastern European feminisms based on the sources that are available. No more, no less. These sources include book chapters and academic journal articles that the author has run into recently. The selection range is in no doubt far from being inclusive in comparison to the bulk of scholarship on this topic. Nor it is statistically representative. Rather, the article resorts to a kind of 'mosaic' methodology, picking up some pieces here and there and piece them together to let a pattern to emerge. For this very reason, the article should not be read as a portrait of the ultimate truth of feminism in Eastern Europe but rather as a window display of a small fraction of it. The goal of this article is not to present a panoramic view of what the second world feminism entails. Rather, it outlines some of the core issues in Eastern European feminism and hope that these will provide some raw material for transnational feminist discussion and thought reflections.

\footnotetext{
${ }^{1}$ See http://www.ask.com/geography/countries-make-up-eastern-europe-f220b8cc461d2e4d.

${ }^{2}$ See http://www.weastra.com/cee-countries/
} 
The article is structured as the followings. Section 1 gives a brief account of the trajectory of the post-socialist transition in Eastern Europe, particularly the change of gender relations and gender discourses, with a delineation of the variations and diversities among the major Eastern European countries; Section 2 views briefly how Eastern Europe has encountered Western feminism and what influences the latter has had in the development of feminism in the region; Section 3 summarizes the main standpoints of Eastern European feminisms and examines how these have challenged the presumptions of Western feminism; Finally, the concluding section discusses the extent to which Eastern European feminisms can become more relevant to the Chinese domestic debates about women, gender and feminism than it is today.

\section{The Centrality of Gender in the Transition to Capitalism: the post- socialist context (s)}

Eastern European feminisms are conceived in the process of transition to democracy and capitalism in the Eastern Europe region and at the same time a critical response to it. Needless to say, 'Eastern Europe' houses a cluster of countries with striking social, cultural as well as political differences. Not only their experiences of the post-socialist transition are different, but also the degree of their success. In terms of economy, for instance, all Eastern European countries 'have a higher level of state ownership and economic control than their Western counterparts', while only Slovenia, Estonia and the Visegrd 'developed market economies based on private ownership of the means of production comparable to what is known from the OECD countries' (Drahokoupil, 2009:286). Some studies hold that 'among post-socialist countries, Belarus, Ukraine, Slovenia and Croatia seem to be examples of countries with prevailing strategic coordination, while Russia, Estonia and Armenia come out as the main examples of liberal economies' (ibid.). In the political aspect, countries like Eastern Germany, Poland, Hungary and the Czech Republic 'were part of the first wave of postsocialist states to join the European Union'.... and 'their status as stable democracies actively engaged with the European Union sets them apart from many other postsocialist states' (Guenther, 2011:866).

One thing the Eastern Europe shares is the centrality of gender in the transition to and from socialism. In Watson's words, "gender relations are intrinsically implicated in the process of change" and "gender, in fact, is present in the very tissue of this change" (Watson, 1993:471). Viewing gender as a construct that "mediates the relation between bodies" and "a symbol system by which bodies enter into sociality" (Verdery, 1996:92), Verdery then quotes the concept of "gender regimes" by R.W. Connell to capture the pivotal role of gender in the historical changes having taken place in the Eastern Europe. Gender regimes "consist of a gender division of labor, a gendered structure of power, and a structure of cathexis" (ibid.). To apply this term to the Eastern Europe, then what has appeared across the region is actually a reconfiguration of gender relations and gender roles -the working and reworking of the gender regime. During the socialist period, many countries in Eastern Europe featured a strong socialist regime which was determined to transform the society through attacking and altering traditional gender structure and roles. These socialist regimes were in favor of 
gender equality' (ibid.) and they promoted policies 'to increase women's participation in the work force' (ibid.) as well as in political decision making of various levels. The socialist gender regime, in the Eastern European contexts, is thus characterized by full-time participation of women in the labor force, certain degree of change in family structure and 'male and female household roles' (ibid.), and a significant degree of visibility of women in politics, both in terms of participation and leadership.

In the transition to democracy and capitalism, these earlier socialist states have moved away from the once proclaimed gender equality and towards a turning back to the structure of gender order in their various pre-socialist epochs. However national circumstances may vary, there have been "consistent and quite clear empirical indications" of reversion of the course of gender equality across the Eastern Europe (Watson, 1993:471). The earlier socialist gender regime was turned upset down, leading to the decline of women's political representation, the rising unemployment rate among women, and a return to traditional values and traditional gender roles -in Verdery's words, 'retraditionalization' of women (Verdery, 1996:100). These negative consequences for women are both motivated by and a result of the following trends of change that has been commonly observed in Eastern Europe, though with national variations in degree and intensity.

The first such trend of change is what Verdery calls for 'de-communism politicking'. It is the politics of volte-face reversal aimed at upsetting whatever has been achieved or extolled under socialism. This politics 'involves 'othering' women as allies of the Communists" (ibid.). And because 'everything the communist parties advocated is discredited..., women's emancipation is just one of the casualties' (Lippe \& Fodor, 1998:132).

The second trend of change in post-socialist Eastern Europe is the 'reestablishment of the sharp distinction between public and private' (Grabowska, 2012:389; Watson, 1993). After the dissolving of state socialism, the family/household has once again assumed central importance (Watson, 1993:481), and women are increasingly 'become identified with the family' (ibid., p.478). In this process, the Churches, especially the Catholic Church in Poland, have played a pervasive role in reinforcing 'the message that women's appropriate place is in the home, outside the labour force' (Lippe \& Fodor, 1998:132). The Churches did so through the 'revocation of abortion rights, the reintroduction of nationalist symbols... and the dissemination of constricting ideas about women's proper sexual behavior and personal character' (ibid.). The regaining of a 'traditionally prescribed gender identity', for Watson, 'is an important aspect of the nostalgia for "normality" which has been so often expressed as what people most hope for from the change in Eastern Europe' (Watson, 1993:472-473).

In the third place, and closely related to the second, is the rise of gender essentialism. On the one hand, the rising civil society and democracy in Eastern Europe 'fundamentally entails the 
construction of a "man's world" and the propagation of masculinism in the public sphere' (ibid., p.472). Consequently, women were phrased out from party politics, and many national parliaments in Eastern Europe 'have become much more clearly the preserve of men' (ibid., p. 473). On the other hand, essentialist popular writings propagated the idea of 'natural difference' between sexes and homemaking roles as the function suitable for women's nature. The earlier state socialism was blamed for having encouraged women to be aggressive in society, causing the loss of their nature and feminine qualities. In Hungary, for instance, popular writings conveyed a strong articulation of men's dismay over masculinized women. They ridicule the 'matriarchy' of socialism and yearn for a restoration of the father's authority and women's dependence on their husbands (Verdery, 1996:100). As Watson rightfully points out, the post-socialist development in Eastern Europe is marked by the 'domestication and marketing of women, and the de-grading of feminine identity (Watson, 1993:472).

The fourth trend of change is the surge of nationalism and strong political conservatism (Selecl, 1992; Bracewell, 1996; Roman, 2001). According to Verdery, what has been evident commonly in post-socialist Eastern Europe is the 'increasingly visible ethnonationalism, coupled with anti-feminist and pro-natalist politicking' (Verdery, 1996:100). Perhaps the issue of abortion illustrates best why nationalism in Eastern Europe is at the same time antifeminist, for abortion involves the idea of the nation's rebirth, and the 'nation cannot be reborn if fetuses - and the nation with them- are condemned to death'. In other words, the nation cannot return to health if its women refuse to bear and nurture its 'fetal citizens.' The nation's recovery from socialism, as Verdery point out, 'requires, then, a new patriarchy, instituted through a new democratic politics that serves the national idea' (ibid., p.101). Feminism, entailing the idea and practice of free abortion, is hence deemed as anti-national and an enemy of the new rising nations.

Altogether, these four trends of change constituted a 'conservative revolution' which has swept the Eastern Europe and has fundamentally altered gender relations in post-socialist Eastern European societies. While both men and women were affected by the economic and sociopolitical transition process in various degrees, the distribution of new rights and of new social power 'is taking place in a strictly gendered way, being fundamentally determined by the prerogative of the masculine' (Watson, 1993:473). The recuperation of the nation and men's pride has taken place 'at the expense of not only voluntary but also involuntary exclusion of women from the new public sphere, and essentially involves the de-grading of feminine identity' (Watson, 1993:485). This, as Watson puts, is a vivid reminder of what Giddens has once said, (m)odernity .......produces difference, exclusion and marginalization' (Giddens, 1991:6, quoted from Watson, 1993:485). 


\section{The Arrival of Western Feminisms: Feminism-by-design and Cultural Feminism}

Eastern Europe entered the phase of transition and opened up for the West after the fall of the Berlin War and the collapse of state socialist regimes, The omnipresent presence of Western influence in the post-socialist Eastern Europe is vividly captured by what Stark calls for 'capitalism-by-design' (Stark, 1992). The term 'capitalism-by-design' grasps the swift influx of Western capital and advisory aid 'into the former Eastern bloc' (Ghodsee, 2004:729). As Ghodsee has described, a virtual army of consultants and experts descended into capital cities to fashion the foundations of capitalism and liberal democracy from scratch. They 'advised local governments on how to create the institutions of democracy and capitalism', believing that once the proper institutions are created in a country then 'the rules of these new institutions would guide individual behavior', so the conditions for the development of capitalism could actually be created by design (ibid.).

In parallel to the Western 'design' for capitalist development in Eastern Europe, Western feminism has also made its' grand entrance into the former Eastern bloc. Jumped on the aid bandwagon during the early transition period, Western feminists and women's organizations began to transfer their aid money, their scholarship/theories on women, and organizational models to the Eastern European recipients ${ }^{3}$. Ghodsee calls this for 'feminism-by-design' (Ghodsee, 2004). As a result, 'gender', as a new analytic concept, was introduced, and 'gender discourses have been appearing at an increasing rate over the last two decades as part of a so-called 'transition to democracy' (or 'open society'), a focus which has been understood as an important requirement toward integration into the European Union' (Millán, 2015:1). At the same time, '(E)ach country was encouraged to have some kind of 'national machinery' in place to deal with women's issues' (Ghodsee, 2004:731), and 'other institutions of Western feminism -the women's advocacy groups, the gender think tanks, the battered women's shelters, the rape crisis hotlines, the women's resource centers, and so forth -began springing up everywhere throughout the former communist countries' (ibid.). Many of these NGOs 'were either directly funded by large multilateral and bilateral donors or supported by Western women's organizations subcontracted by USAID or the European Union's Poland and Hungary' (ibid.). Many scholars have used the term NGOization to capture the rapid development of women NGOs in the Eastern bloc (Guenther, 2011).

In short, Western feminism, as women in post-socialist Eastern Europe have encountered, experienced and are still trying to digest, is both ideological and material in form. It consists of a body of theories about gender (hereunder a vast scholarship on women in the transitional Eastern Europe produced in the light of gender analysis), and a whole wide spectrum of women's organizations and NGOs that were established to create a civil society which are

3 For the three-stage process of institutionalization and gender mainstreaming in Eastern Europe, see (Zimmermann, 2007). 
believed as necessary for the development of democracy and for solving the problems facing women. While having helped to boost feminist theorizing (in terms of gender and women's studies) and organizing in Eastern Europe in the early transitional phase, the influence of Western feminism has increasingly met with doubt, critique and resistance later on. Critics of the gender concept, for instance, have coined the term 'cultural feminism' to decode the core idea of Western feminism encapsulated in 'gender'. Cultural feminism refers to 'a specific package of discourses and practices that promote the idea that women and men are essentially different'.....these differences between the two sexes transcend class, race, age and ethnicity and supposedly unite all women in a common sisterhood'....Cultural feminism 'looks to find solutions for how the worst offenses of patriarchy can be mitigated, while never challenging the social and economic relations within which patriarchy thrives'. Moreover, Ghodsee points out that cultural feminism, 'as a way of addressing women's concerns', 'works well within the neoliberal ideological constraints of the large bilateral and multilateral aid institutions in the West' (Ghodsee, 2004:728). This critical reflection of 'gender' is both a necessary step for Eastern European Feminisms to come out of the shadow of western feminism and a lively manifestation of their ability to do so.

\section{Eastern European Feminisms}

Eastern European Feminisms - alternatively Second World feminism or post-socialist feminism- challenge the hegemony and the assumed universal applicability of Western feminism. They proclaim the rightful place of their geopolitical and historical positioning in the production of feminist knowledge; insist on the relevance of their own tradition/cultures in shaping women's lives as well as women's own understanding/reflection of their lives; and they call for a cautious treatment of the socialist past so that the legacy of state feminism can be fully excavated and reevaluated for the advantage of women and feminist politics in today. In the following, I will delineate the main tenet of Eastern European feminism in four aspects.

First of all, Eastern European Feminisms reject the hegemony of Western feminism and this rejection has its' source of inspiration in postcolonial theories (Said, 1978; Mohanty, 2003). Among the CEE feminist scholars, for instance, there is a concerted concern over the 'power relations... within the global academic political economy .... and how these power relations operate in the discipline of women's and gender studies' (Cerwonka, 2008:809). They 'highlighted the following features in this unequal relationship: theory is modeled on Western realities; English is the dominant language in research and conferences; less research money is available to CEE scholars than to their Western counterparts; and greater institutional funding in the West means that CEE scholars are positioned as guests of Western institutions, even at conferences held in their own region' (ibid., 810.). In addition, 'the most prestigious journals publish only in English and look more favorably on research that follows AngloAmerican conventions of argumentation and that cites Western scholarship' (ibid.). ${ }^{4}$ Because

\footnotetext{
${ }^{4}$ For more about this point, see (Busheikin, 1997).
} 
of the persistence of these conditions, CEE feminist scholars feel being 'colonized' in the sense that they found themselves being relegated to the position of acting as 'transmitters' of Western feminism instead of as an independent agent of new knowledge (ibid.). ${ }^{5}$

Eastern European Feminisms also criticize the often-assumed West versus East, North versus South binary and advocate for alternative way to think about transnational feminism. For CEE feminists, the rigid geopolitical divides such as West/East and North/South poses a number of problems for transnational feminist dialogues. One is that 'the feminist movement in the West has been taken as the feminist movement' (Cerwonka, 2008:810) and some of the Western feminist concepts, rooted in their particular history and cultural context, have assumed the status of universally applicable 'truth'. As a result, the theorization of important gender issues in post socialist societies has unfortunately been done 'in the shadow of an already wellestablished feminist legacy from North America and Western Europe' (ibid., 811), and 'when the social reality of CEE societies deviates from established theories, Western scholars tend to judge these societies as underdeveloped rather than question the applicability of the theory' (ibid., 812). Moreover, 'the overwhelming majority of Western scholars who have written about gender and economic transformation have tended to paint a very dark picture of women's position in the emerging postsocialist societies' (Ghodsee, 2004:730), and there is a false assumption that 'East European women are second-class citizens and that they are conservative' (Havelkova, 1996:243, quoted from Cerwonka, 2008:812). While CEE women were represented as the lesser enlightened and lesser progressive 'other' in the Western feminist scholarship which is often biased, incomplete and misleading, the rich details and dynamics of CEE feminist movements go either unnoted or ignored as the true feminist movements in their own rights.

In their revolt against the hegemony of Western feminism, CEE feminists also feel unease about the first and the third world constellation as 'a central point of postcolonial inquiry' because 'the second world remains largely absent from anti-imperialist discourses' (Grabowska, 2012:400). One evident example is the UN's Fourth World Conference on Women in Beijing in 1995 which provided the first opportunity for many CEE feminists to enter the global feminist forum. The participation in the conference gives, however, a feeling of being left outside: the 'South-North paradigm was already defined' and many CEE feminists found it extremely hard to enter that space (ibid.). Although the UN conference 'became a platform for developing transnational dialogue on the complex meanings of the politics of location and for connecting the U. S. debate around the intersection of gender and race with the struggle of the women representing the global South, it also created a paradigm within which 'third-world women' became a substitute for 'women of color' (ibid, 401-402) where women from the Eastern Europe do not belong. The difficulties that Eastern European feminists have experienced with the UN's world conference on women, as Grabowska points out, lie in their 'inability or refusal to formulate its regional identity' within the First World

\footnotetext{
${ }^{5}$ See (Blagojević ,2004).
} 
versus the Third World diagram (ibid.9). Ironically, CEE feminists were classified as women from the non-region in the UN documents on women because they 'found it difficult to identify with the struggle of third-world women' (ibid.).

Secondly, Eastern European Feminisms contest the concept 'gender' and the universal applicability of 'gender'. Since 1989, gender and gender-based women's studies were 'imported' into the postsocialist countries from the West. Initially, the concept of gender was widely accepted and used as a new approach to analyze women's problems under the transition and women's studies have been institutionalized in many CEE countries. But critiques of gender and gender approaches have been on rise lately, marking a bold departure from the imported Western feminist theories in the Eastern European feminists' search for their own identity. It is pointed out that many women in the CEE countries actually do not, and also refuse to, identify themselves with gender and the supremacy of gender analysis. Many 'saw the sudden arrival of cultural feminism in the former socialist countries as a foreign and unwelcome ideology' (Ghodsee, 2004:733). Many CEE women find it odd to see themselves in terms of gender, the opposite gender of men, since they had fought for their course in alliance with men during the socialist period (Solidarity case??). Therefore, they 'do not perceive that their situations (under the transition) are different from men's', and hence 'refuse to separate out their problems from those of men' (Ghodsee, 2004:736, 735). Moreover, many are convinced that, mostly before 1989 but also now, bourgeois feminism, as a tool of capitalism, is 'complicit in the process of exploitation that capitalism perpetuated' (ibid.).

Eastern European Feminisms question the applicability of gender and Western feminism for a number of reasons. One is due to the ill fit between the life experiences of CEE women and Betty Fridan's sense of 'emptiness and non-existence' in being a housewife. As Slavova points out, prior to 1989 women in CEE countries 'were expected to work by a socialist state that claimed to have already emancipated them'. To work is therefore not a privilege to fight for as Betty Fridan yearned in her book the Feminine Mystique. Thus, what has been important for Betty Fridan and Western feminism provides thin ground for CEE women to identify with exactly because of the political and cultural differences between the West the CEE countries (Slavova 2006:248, quoted from Cerwonka, 2008:814). Moreover, Eastern European Feminisms are particularly scathing of the blind adoption of 'gender' and Western feminist discourses. They see it as a pity that the notion of gender was generally accepted during the 1990s without being 'deeply explored or examined from the inside out' and that gender 'became a free-floating signifier marking an epistemological time-lag' (Kasic, 2004:480, quoted from Millán, 2015:10). Some even criticize 'gender' and Western feminism for not only 'fail to explain social phenomena adequately' but also for might having been 'complicit in creating social cleavages where none previously existed' (Cerwonka, 2008:813). Watson, for instance, argues that 'to focus exclusively on an idea of gender in postcommunism which compares "men" on one side and "women" on the other-is to endorse the underlying terms of transition, terms which themselves are productive of masculinism' 


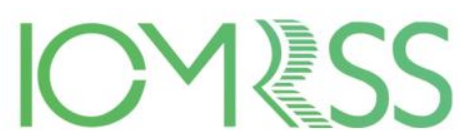

06-08 November, 2020

MUNICH, GERMANY

(Watson, 2001:46, quoted from ibid,). For Zimmermann, although 'the institutionalization of gender and women's studies in Eastern Europe and the former Soviet countries can be seen as an opportunity to develop critical feminist thinking, it nevertheless functions as 'a neoliberal instrumentalization and cooptation of the gender discourse as solely gender equity without any social and political critique of Western liberal democracy and the capitalist market' (Zimmermann, 2007).

In the eyes of Eastern European Feminisms, the major problem with 'gender' is that: one, gender narratives often codify women in CEE countries as 'a homogenous group sharing universal conditions of life under state feminism, as well as the experience of social transformation' (Grabowska, 2012:386), whereas in contrast there have been notable national and sub-regional variations and diversities concerning women and gender relations (Guenther, 2011:868). Eastern European Feminisms thus contest that in the Eastern European contexts, "political solidarity cannot be assumed on the basis of shared "womanhood" (Gal \& Kligman, 2000:106, cited in Ghodsee, 2004:735), and they express the need to move away from Western feminist frames so as to reestablish the local genealogies of feminism, for instance, Polish feminism (Grabowska, 2012:392). Two, 'gender' and Western feminism ignores 'other salient social categories like class in their analysis of Eastern Europe and thereby mystifying the real social factors that limit democracy in these societies (quoted from Cerwonka, 2008:813). The concept of gender, as an essentialist category of difference, contradicts the fact that 'the social class of a woman before 1989 is a more significant determinant of success in the market economy than merely gender alone' (Ghodsee, 2004:736), and it 'fails to recognize the complexity of the postsocialist context and the importance of understanding emerging class distinctions in societies still very much in touch with Marxist-Leninist ideals of social justice' (Ghodsee, 2004:748). Millán thus suggests that feminism (s) in Eastern Europe need to be reflective on the meaning of 'gender' in different contexts and the 'translatability' of gender as well (Millán, 2015:13)

Thirdly, Eastern European Feminisms oppose the view of state socialism either as something taken for granted or as 'a detrimental gap in the development of a Western-style liberal identity' (Grabowska, 2012:396). They call for a thorough reevaluation of the state socialism legacy, insisting that the effects of state feminism are far from being fully investigated or comprehended and must therefore be further examined with caution and care. While recognizing that the socialist gender revolution was incomplete...., the regime's commitment to equality was quite limited.... and the provisions offered by the socialist state were superficial (Grabowska, 2012:397), Eastern European Feminisms view 'the state socialism's effects on feminism rather as 'much more complex' (ibid.). Some, for instance, argue that 'at the personal level, the period of state feminism has a more complex impact on women's lives, representing an opportunity for self-education and indeed becoming an impetus for establishing women's activist communities' (pp. 398). Others hold that women 'were not only victims; they were also creators and implementers of state-socialist equality policies. 
Working-class women, for instance, have gained 'greater economic and sexual autonomy' and the opportunity 'to formulate their interests and ideas' (ibid., 398).

In Poland, many Polish feminists began to move away from liberalism. They realized that 'normal feminist trajectory emerged from specific geopolitical, cultural, and historical locations characteristic of Western societies, and is thus largely irrelevant to the lived experiences of women in Poland' (Grabowska, 2012:396; 392). They turn to reevaluate and appreciate their own indigenous feminist legacy derived from socialism and emphasize the need to 'reestablish the local genealogies of Polish feminisms' (pp. 392). In reappraising the role of Solidarity, for instance, many polish feminists point out that 'in their experience, Solidarity played a crucial yet not always obvious role in linking feminism and politics' (pp. 393). They refuse to accept the assumption that 'the West as the only logic point of reference for 'provincial' Eastern European feminisms' (Grabowska, 2012:392) because such assumption 'discounted the impact of local legacies on the trajectory of Polish feminism' (ibid.). As a Polish feminist has expressed, feminism is not about importing stuff from the West, the United States, 'there was always something here - a tradition of women's emancipatory thinking' (Grabowska, 2012:392). The 'idea of rerooting feminism in local narratives of inequality' (pp.393) has boosted the confidence of CEE feminists. And it is based on this confidence that they claim their contribution to feminism, their version of feminism and an understanding of feminism, not as 'difference and geographical separateness' but rather 'in terms of 'copresence', interaction, interlocking understandings and practices...' (Pratt, 1992:7, quoted from Cerwonka, 2008:825).

Fourthly, Eastern European Feminisms examine NGO feminism and the effects of NGOization with critical eyes. In the process of transition to democracy and capitalism, 'a feminist civil society has emerged at more local levels' in Eastern European countries (Guenther, 2011:868). It is estimated that 'there are two hundred feminist and women's organizations in Poland and in eastern Germany and fewer than one hundred such groups in Hungary and the Czech Republic (Šiklová, 1997; Fuszara, 2000). Most of the women's NGOs in the region 'takes the two-pronged approach of offering services and engaging in advocacy work', whereas there has been 'relatively little direct organizing to facilitate women's participation in formal politics and even less to push for the inclusion of feminist women or feminist goals in formal politics' (Guenther, 2011:870, 871). According to Guenther, feminist mobilization in CEE countries 'has centered on building feminist civil society', and this feminist civil society 'emerged from two different sources'. One 'are locally created groups founded by concerned women who banded together to mobilize around an issue that affects them or their community, and one 'are externally created organizations developed through INGOs, where agendas are set by policy actors who may not be part of a particular community' (ibid. 871). 
One critique of the Eastern European Feminisms targets at the international NGOs (INGO) who usually provide funding for domestic NGOs. According to Guenther, INGO funding is ' $\mathrm{a}$ mixed blessing for local NGOs'. While the funding has undoubtedly benefited the local NGOs financially, many local NGO organizers 'sometimes feel pushed in certain directions to appease donors' (Guenther, 2011:872). Some INGOs impose 'their agendas and ideologies on women in Eastern and Central Europe with little regard for local concerns and issues' (ibid., referring to (MacMahon, 2002). MacMahon directs her critique toward the model of funding of INGOs. They typically offer short-term, project-based funding, which, in the view of MacMahon, is 'problematic on a number of fronts. First, this model of funding 'creates a climate of financial insecurity for feminist organizations and their employees'. This in turn 'increases workplace stress and sometimes serves to heighten competition among feminist organizations and the employees who work in them as both groups and individuals vie for continued funding' (ibid.). Second, 'project-based funding is inevitably limited in its scope in terms of both time and content. The funded projects 'typically focuses on short-term results for a small group of beneficiaries' and are hence unable to 'address large social problems or promote long-term social change'.

Many feminist scholars in the CEE countries use the term 'NGOization' to sketch the proliferation of NGOs in the region. They also use the term 'NGO feminism' to delineate the part of feminist civil society which, with the funding from INGOs, typically 'focus on a small subset of issues facing women and emphasize pragmatic responses to those issues' (Guenther, 2011:874, see also Lang, 1997). They thus question the effects and hence the primacy of NGO feminism, arguing 'how successful can they be when they are dependent on exactly the structures that need to be transformed?' (Lang, 1997:113, quoted from Guenther, 2011:874). For Guenther, there are several reasons for being skeptic towards NGO feminism. One, NGO feminism 'neutralizes feminism through professionalization, specialization, and bureaucratization; two, NGOization 'discourages the growth and maintenance of feminist subcultures that resist hegemonic gender relations; three, NGOization 'inhibits the ability of feminists to articulate and make claims', and four, NGO feminism 'fail to challenge existing structures of civil society, the state, and the economy that perpetuate gender and other inequalities' (Guenther, 2011:874).

In her scrutiny of women's NGOs in Ukraine, Hrycak critically examines the roles of women whom she calls 'foundation feminists' and how they mediate the 'encounter between foreign aid and local organizing' as a kind of broker go-between (Hrycak, 2006). 'Foundation feminists', according to Hrycak, are usually women of local origin with high education and fluent English-speaking capability. They were considered by foreign donors to be experts in women's empowerment, and they were hired to work as staff and advisors on U. S. projects to foster grassroots women's activism (Hrycak, 2006: 84, 72). Many of them have been trained as gender experts by American foundations and serve as the primary formal gatekeepers of aid to grassroots women's organizations in Ukraine (ibid., p. 84). The problem with these foundation feminists lies in that although 'their experience, education and social status 


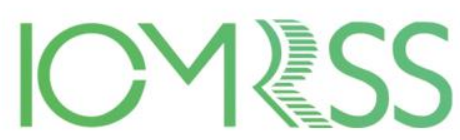

06-08 November, 2020

MUNICH, GERMANY

enabled them to embrace' foreign donors' analysis of 'Ukrainian women's problems', few of them 'have ever worked with the informal, grassroots community associations' (ibid.). They 'resemble their Western counterpart in their view on women': having accepted foreign donors' representation of 'local traditions as the source of women's difficulties' and seeing 'tradition as an obstacle' to women's choice under the transition (ibid., p. 85). As so, foundation feminists 'often had little sympathy for the causes and concerns that inspired the local women's activism that existed locally', and they 'rarely took an interest in local materialists' (ibid., p. 86). On the contrary, they tend to view the dominance of materialists I Ukraine as evidence of the country's 'backwardness' relative to the rest of the world' (ibid.). They were 'generally hostile to the causes and grievances that inspired local women's activism', and they prefer to work with those who 'also accepted that tradition is oppressive and the source of post-Soviet women's dilemma' (pp. 86, 85).

In a parallel, Hrycak also pinpoints two undesirable effects of the NGOization driven by foreign foundations. One is the uneven distribution of funding sources among women's organizations. While 'most local women's organizations have no funding, elite NGOs run by foundation feminists 'attract considerable grants' and hence be able to 'pay their staff sizeable incomes' (ibid., p. 88). And since 'far more success in fund-raising has been achieved by' elite NGOs and elite foundation feminists, they actually 'drained resources and key personnel away from the local groups of citizens who were becoming active in public life 'from below' (ibid., p. 86). The other problem is that 'foreign aid encouraged the formation of 'hybrid' organizations' (pp. 97-98). Since the organizations that oriented toward the language spoken by foreign elites and foundation staff (pp. 98) are favored, many women's organizations cater to the donors' requirement by adopting various organizational and communicative strategies even though they are not strictly nongovernmental and nonprofit kind. Some 'local hybrids are extensions of state socialist activism, while 'others are local feminist organizations that exist only on paper' (ibid.). In sum, 'foreign funding practices spurred the development of hybrids that little resemble the organizations that designers of civil society projects intended to promote in post-Soviet countries' (ibid.). 


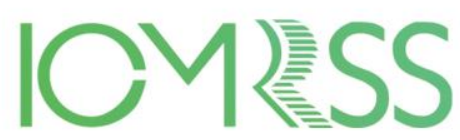

06-08 November, 2020

MUNICH, GERMANY

\section{Discussion and Conclusion: China and Eastern Europe}

It can be argued on the ground of two reasons that China has not undergone a full-fledged conservative revolution as the Eastern Europe has. One is the still-in-power of the Chinese Communist party, and one is the deficiency of Church influence in the post-socialist Chinese politics. In terms of gender and gender relations, however, China has lot more in common with its Eastern European counterparts. The market development in China have borne a series of consequences for women, and, like the de-communist politicking in Eastern Europe, China's post-Mao transition to a market economy also involves a ridicule of the previous socialist pro-women policies and a subsequent reworking of gender order and relations. In China, it was mainly the Cultural Revolution and the notable progress in women's liberation achieved during that period that were repudiated. In post-Mao China, there is also a concerted call for women to rediscover their nature; a plea for women to shrink from their public role in society; and a demand for women to return to family and kitchen as full-time housewives.

What more strikingly similar between post-socialist China and Eastern Europe is the trajectory of feminist development in both theory and organizing. Like in the Eastern Europe, Western feminism also made an entrance into China and exerted a great deal of influence on the development of feminist thinking and feminist activism in China. The concept of 'gender', unknown to China before, was introduced into China and widely adopted in academic research; women's studies mushroomed and institutionalized throughout the country; 'cultural feminism' thrived; and foreign donors/INGOS have been highly visible in the development of women's NGOs and feminist civil society in China. In this context of strikingly similarity, perhaps it is on time for us to look eastward and find new sources of inspiration from there. It is perhaps on time for us to critically examine the asymmetrical power relations between Western feminism and ourselves, asking what we have achieved in terms of feminist theorybuilding after all these years apart from transmitting and using Western feminist theories? Perhaps we should carefully reconsider the legacy of China's state-socialism and its potential as an indigenous ground for Chinese feminism, or perhaps we should align with Eastern European feminism and join them in the contestation of Western feminist hegemony? As Young puts, 'Chinese feminists may find it useful to learn from other socialist counterparts' (Yang, 2011:345). 


\section{References:}

Blagojević, M. (2004). Creators, Transmitters and Users: Women's Scientific Excellence at the Semi-periphery Europe. Gender and Excellence in the Making. Brussels: European Commission Research Publications, pp.135-46.

Bracewell, W. (1996). Women, motherhood, and contemporary Serbian nationalism, Women's Studies International Forum, Volume 19, Issues 1-2, pp. 25-33.

Busheikin, L. (1997). Is Sisterhood Really Global? Western Feminism in Eastern Europe. Tanya Renne ed., Ana's Land: Sisterhood in Eastern Europe. Boulder: Westview, pp. 12-21.

Cerwonka, A. (2008). Travelling Feminist Thought: Difference and Transculturation in Central and Eastern European Feminism, Signs: Journal of Women in Culture and Society, vol. 33, no. 4, pp. 809-832. Available: http://www.jstor.org/stable/10.1086/528852.

Drahokoupil, J. (2009). After Transition: Varieties of political-economic development in Eastern Europe and the Former Soviet Union, Comparative European Politics, vol. 7 (2), pp. 279-298.

Fuszara, M. (2000). Feminism, the New Millennium, and Ourselves: A Polish View, Signs: Journal of Women in Culture and Society, vol. 25(4), pp. 1069-75.

Gal, S. and Kilgman, G. (2000). The Politics of Gender after Socialism- A comparativehistorical Essay. Princeton \& New Jersey: Princeton University Press.

Ghodsee, K. (2004). Feminism-by-design: Emerging Capitalism, Cultural Feminism, and Women's Nongovernmental Organizations in Postsocialist Eastern Europe, Signs: Journal of Women in Culture and Society, vol. 29 (3), pp.727-753. Available: http://www.jstor.org/stable/10.1086/380631. 
Giddens, A. (1991). Modernity and Self-Identity. Cambridge: Polity Press.

Grabowska, M. (2012). Bringing the Second World in: Conservative Revolution (s), Socialist Legacies, and Transnational Silences in the Trajectories of Polish Feminism, Signs: Journal of Women in Culture and Society, vol. 37 (2), pp. 385-411.

Guenther, Katja M. (2011). The Possibilities and Pitfalls of NGO Feminism: Insights from Postsocialist Eastern Europe, Signs: Journal of Women in Culture and Society, vol. 36 (4), pp. 863-887, Available: http://www.jstor.org/stable/10.1086/658504,

Havelkova, H. (1996). Abstract Citizenship? Women and Power in the Czech Republic, Social Politics, vol. 3(2-3), pp. 243-60.

Hrycak, A. (2006). Foundation Feminism and the Articulation of Hybrid Feminisms in PostSocialist Ukraine, Easter European Politics and Societies, vol. 20 (1), pp. 69-100. DOI: 10.1177/0888325405284249.

Kašić, B. (2004). Feminist Cross-mainstreaming within 'East-West' mapping: A postsocialist perspective, European Journal of Women's Studies, vol. 11(4), pp. 473-485.

Lang S. (1997). The NGOization of feminism. In Scott JW, Kaplan C and Keates D (eds). Transitions, environments, Translations: Feminism in Contemporary Politics. New York: routledge, pp.101-120.

Lippe, T. and Fodor, E. (1998). Changes in Gender Inequality in Six Eastern European Countries, Acta Sociologica, vol. 41 (131), pp. 132-149. Dol: 10.1177/000 169939804 100203.

MacMahon, P.C. (2002). International Actors and Women's NGOS in Poland and Hungary. In Sarah E. Mendelson and John K. Glenn ed. The power and Limits of NGOS: A Critical Look at Building Democracy in Eastern Europe and Eurasia, New York: Columbia University Press, pp. 29-53.

Millán, M.(2016). The Travelling of 'Gender' and its accompanying baggage: Thoughts on the translation of feminism (s), the globalization of discourses, and representational divides, European Journal of Women's Studies, vol. 23(1), pp.1-22. 
Mohanty, C. T. (2003). Under Western Eyes" Revisited: Feminist Solidarity through Anticapitalist Struggles, Signs: Journal of Women in Culture and Society, vol. 28 ( 2), pp. 499-535. Avaliable: http://www.jstor.org/stable/10.1086/342914 .

Pratt, M. L. (1992). Imperial Eyes: Travel Writing and Transculturation. London: Routledge.

Roman, D. (2001). Gendering eastern Europe: Pre-feminism, prejudice, and east-west dialogues in post-communist Romania, Women's Studies International Forum, vol. 24 (1), pp. 53-66.

Selecl, R. (1992). Nationalism, Anti-Semitism, and Anti-feminism in Eastern Europe, New German Critique, no. 57 (autumn), pp. 51-65. Avaliable: http://www.jstor.org/stable/488441,

Stark, D. (1992). Path Dependence and Privatization Strategies in East Central Europe, East European Politics and Societies, vol. 6(1), pp.17-54.

Said, E. (1979). Orientalism. New York: Vintage Books.

Slavova, K.(2006). Looking at Western Feminisms through the Double Lens of Eastern Europe and the Third World.In Jasmina Liikc, Joanna Regulska and Darja Zavirsek ed., Women and Citizenship in Central and Eastern Europe. Aldershot: Ashgate, pp. 245-264.

Šiklová, J. (1997). Feminism and the Roots of Apathy in the Czech Republic, Social Research, vol. 64 (2), pp. 258-80.

Verdery, K. (1996). From Parent-State to Family Patriarchs: Gender and Nation in Contemporary Eastern Europe. In Verdery, Katherina, What Was Socialism and what Comes Next. Princeton: Princeton University Press, 1996, pp. 61-82.

Watson, P. (1993). Eastern Europe's Silent Revolution: Gender, Sociology, vol. 27 (3), pp. 471-487. DOI: 10.1177/0038038593027003008.

Watson, P. (2001). Gender and Politics in Postcommunism. In Gabriele Jähnert, Jana Gohrisch, Daphne Hahn, Hildegard Maria Nickel, Iris Peinl, and Katrine Schäfgen ed. 
Genden in Transition in Eastern and Central Europe, Proceedings, Berlin: trafo verlag, pp. $37-48$.

Yang, J. (2011). Nennu and Shunu: Gender, Body Politics, and the Beauty Economy in China, Signs: Journal of Women in Culture and Society, vol.36 (2), pp. 333-357. Avaliable: http://www.jstor.org/stable/10.1086/655913,

Zimmermann, S. (2007). The Institutionalization of women and gender studies in higher education in Central and Eastern Europe and the former Soviet Union: Asymmetric politics and the regional-transnational configuration. Symposium of Gender, Empire and the Politics of Central and Eastern Europe: A Gender Symposium, Central European University, Budapest, Hungary, 17-18 May. 